\title{
A Comparative Study of Four Different Non-Isolated Bidirectional DC-DC Converters
}

\author{
${ }^{*} \mathrm{~K}$ V Nirmala ${ }^{1}, \mathrm{~S}$ Arulmozhi ${ }^{2}, \mathrm{~K}$ Sundararaman ${ }^{3}$ \\ ${ }^{I}$ ME Student, Dept. of EEE, Sri Venkateswara College of Engineering, Sriperumbudur, India \\ ${ }^{2}$ Assistant Professor, Dept. of EEE, Sri Venkateswara College of Engineering,Sriperumbudur, India \\ ${ }^{3}$ Associate Professor, Dept. of EEE, Sri Venkateswara College of Engineering,Sriperumbudur, India \\ Corresponding author: $* K$ V Nirmala
}

\begin{abstract}
Inthis paper, four different topologies of Non-Isolated Bidirectional DC-DC converters are compared. Their modes of operations and the design of passive components are presented in detail for all the topologies. The selected topologies are simulated by using MATLAB /Simulink to verify the effectiveness of the converters. The simulation results and comparative studies are used to select the efficient topology. Finally, a 12-V/50-V Prototype model is implemented to verify the feasibility of the converter for the application of Uninterruptible Power Supply
\end{abstract}

Keywords: Bidirectional DC-DC converter (BDC), Uninterruptible Power Supply (UPS), Non-isolated Bidirectional DC-DC converter (NBDC).

\section{INTRODUCTION}

A DC-DC converter is an electronic circuit which converts a source of direct current from one voltage level to another. In renewable DC systems Bidirectional DC-DC converters are used for high voltage and high power applications. It has a capability of power flow in forward and backward directions and can be operated as a step up and step down converter. Bidirectional converters are the main part of a system where it is necessary to interface an energy storage device to renewable energy sources like fuel cell, solar cell etc. therefore bidirectional converters are getting more importance for past decades. Because of theincreasing demand of the renewable energy source batteries are necessary for storing and supplying energy. The renewable energy system cannot provide stable power to the load; the batteries areused for sufficient power. The whole power of the renewable energy system cannot be used completely by the load some amount of energy can be used to charge the battery. In order to charge and discharge the battery, a bidirectional converter is needed which transfer the energy between two sources in both directions. The bidirectional converters can be classified into isolated and nonisolated types. In isolated type $\mathrm{BDCs}$, the major concerns are high switching losses, excessive voltage, current stresses, and significant conduction losses. To overcome these difficulties non isolated BDC (NBDC) topology evolved which are highly cost effective and acceptable due to high efficiency improvement and considerable reduction in weight and volume of the system. Bidirectional DC-DC converters are widely used in many applications such as Uninterruptible Power Supply (UPS) system, aerospace, electric vehicles, PV hybrid power system and many other appliances and industries.

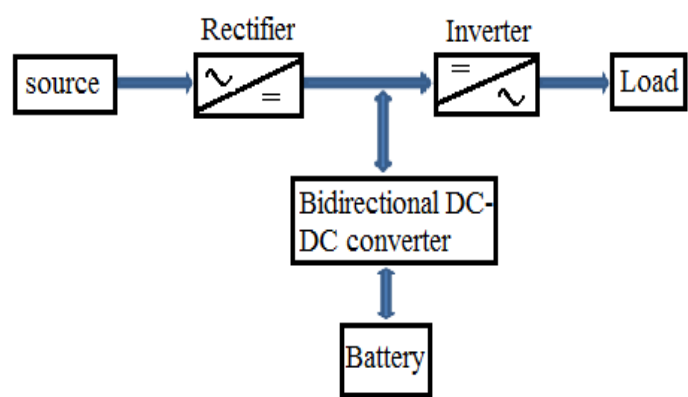

Figure 1. Block diagram of UPS

Bidirectional DC-DC converters are widely used in many applications such as Uninterruptible Power Supply (UPS) system, aerospace, electric vehicles, PV hybrid power system and many other appliances and industries. The block diagram of UPS system is shown in Figure 1. In normal mode the power flows from source to load and also charges the battery, if any faults occur the source gets disconnected then the battery discharges and provides power to the load. Among many topologies implemented for different applications, four topologies are selected and compared to provide the comparative evaluation of the systems. 


\section{OPERATING PRINCIPLES OF THE SELECTED TOPOLOGIES}

The operation and analysis of the four topologies are explained for both Boost and Buck mode.

\section{A. Topology 1}

The topology 1as shown in Figure 2 is a combination of two boost converters that are used to enhance the voltage gain. It comprises four power switches and their body diodes, two inductors and capacitors used to divide the input current which causes the efficiency to be high. Two of the switches are power switches and the remaining acts as synchronous rectifiers [1].

In Boost mode, the switches $S_{1}$ and $S_{2}$ are turned on the switches $S_{3}$ and $S_{4}$ are turned off. The DC source $\mathrm{V}_{\mathrm{L}}$ is transferred to inductor $\mathrm{L}_{2}$. Inductor $\mathrm{L}_{1}$ is magnetized by the DC source $\mathrm{V}_{\mathrm{L}}$ and the energy is stored in capacitor C. Capacitor $\mathrm{C}_{\mathrm{H}}$ on load side is also discharged to the load.

The voltage gain is $\frac{\mathrm{V}_{\mathrm{H}}}{\mathrm{V}_{\mathrm{L}}}=\frac{1}{(1-\mathrm{D})^{2}}$

In buck mode, the switches $\mathrm{S}_{3}$ and $\mathrm{S}_{4}$ are turned on and $S_{1}$ and $S_{2}$ are turned off. The energy of the DC source $\mathrm{V}_{\mathrm{H}}$ is transferred to inductors $\mathrm{L}_{1}$. Capacitors $\mathrm{C}$ is discharged to inductors $\mathrm{L}_{2}$ and capacitors $\mathrm{C}_{\mathrm{L}}$ on battery side. The voltage gain is

$\frac{\mathrm{V}_{\mathrm{L}}}{\mathrm{V}_{\mathrm{H}}}=\mathrm{D}^{2}$

(2)The minimum values of

inductors can be found from the current ripples of the inductors $\mathrm{L}_{1}$ and $\mathrm{L}_{2}$ by using integral form of current equation [1].

$L_{1} \geq \frac{\left(1-\mathrm{D}^{2}\right) \mathrm{R}_{\mathrm{L}}}{2 \mathrm{D}^{2} \mathrm{fs}}$
$L_{1} \geq \frac{\mathrm{R}_{\mathrm{L}}}{2 \mathrm{fs}_{\mathrm{s}}}$

$L_{1} \geq \frac{\mathrm{R}_{\mathrm{L}}}{2 \mathrm{fs}}$

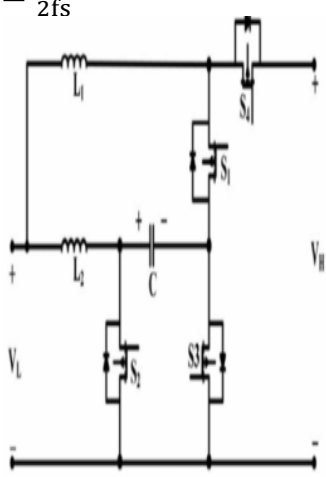

(a)

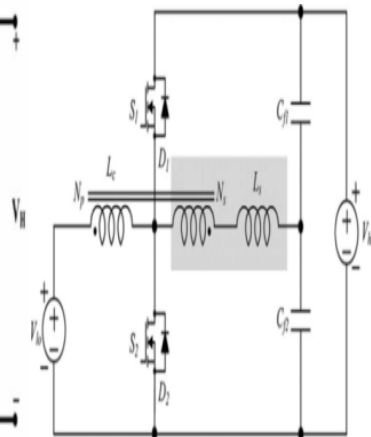

(b)

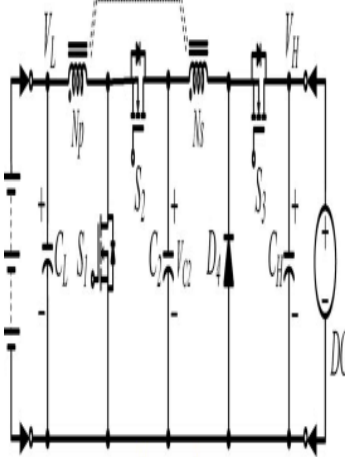

(c)

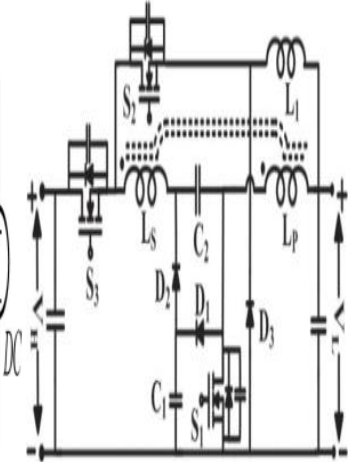

(d)
Figure 2. Non-isolated Bidirectional DC-DC converters (a) topology 1, (b) topology 2, (c) topology 3 , (d) topology 4

\section{B. Topology 2}

A non-isolated bidirectional converter with fixed switching frequency and a ripple free inductor is shown in Figure 3.It utilizes a simple auxillary circuit that consists of an additional winding to the main inductor and an auxillary inductor. The ripple free inductor reduces the voltage ripple [2].

The Boost mode begins with turn of $S_{1}$ with an assumption that the capacitors $\mathrm{C}_{1}$ and $\mathrm{C}_{2}$ are very small and the time interval in this mode is very short, all the currents can be considered as constant and the voltages $V_{S 1}$ and $V_{S 2}$ vary linearly. Now the gate pulse for the switch $S_{2}$ is applied. Since the voltage $\mathrm{V}_{\mathrm{S} 2}$ is maintained as zero at the moment of the turn-

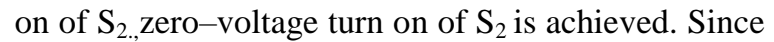
the voltage $\mathrm{V}_{\mathrm{P}}$ across the magnetizing inductance $\mathrm{L}_{\mathrm{M}}$ is $\mathrm{V}_{\mathrm{LO}}$, the magnetizing current increases linearly. Now the gate pulse forthe switch $S_{1}$ is applied, the voltage $V_{S 1}$ is maintained as zero at the moment of the turn of $S_{1}$. In this mode the magnetizing current $i_{m}$ decreases linearly.

$$
\text { The voltage gain is } \frac{V_{H I}}{V_{L O}}=\frac{1}{(1-D)}
$$

(5)From

the modes of operation the inductor currents can be obtained, using those current equations the inductor $\mathrm{L}_{\mathrm{s}}$ can be rewritten as [2]

$\mathrm{L}_{\mathrm{S}}<n(1-\mathrm{n}) \mathrm{V}_{\mathrm{L} 0} \frac{\mathrm{DT}}{2 \mathrm{P}}$

\section{Topology 3}

The converter shown in Figure 4 uses the coupled inductor technique to achieve high conversion ratio with very simple control circuits. In discharging mode the converter acts as two stage boost converter by controlling one power switch to achieve high step up conversion. In charging mode the converter acts as two cascaded buck converters that control two power switches simultaneously to achieve high step down conversion. In conventional buck-boost bidirectional converter the conversion ratio is significantly reduced by parasitic elements. The energy stored on the leakage inductor of the 
coupled inductor causes high voltage of the power switches [12].

During Boost mode the converter steps up the low battery bank voltage to high dc link voltage. Switch $S_{2}$ remains off during this mode. Switch $S_{1}$ is on and $S_{3}$ is off and the low battery voltage is applied on the low voltage side of the circuit. If $S_{1}$ is turned off, the primary $i_{L P}$ charges the parasitic capacitances across switch $S_{1}$, the secondary current $i_{L S}$ discharges the parasitic capacitances across switch $S_{3}$. The leakage inductance causes the primary current to decreases while the secondary current increases. Inductor and capacitor $\mathrm{C}_{2}$ are now connected in series to transfer the energy to high voltage side of the circuit, the energy stored in the primary and secondary discharges across the high voltage side of the circuit.

The voltage gain is $\frac{\mathbf{V}_{\mathbf{H}}}{\mathbf{V}_{\mathbf{L}}}=\frac{\mathbf{n}}{(\mathbf{1}-\mathbf{D})}$

During Buck mode switch $\mathrm{S}_{3}$ remains on whereas the switches $S_{1}$ and $S_{2}$ are off. The current flows from high voltage side to the low voltage side of the circuit through capacitor $\mathrm{C}_{2}$ and both windings of the coupled inductor. $\mathrm{D}_{3}$ is also conducting with continuous inductor current $i_{L 1}$ into the low voltage side of the circuit. When $\mathrm{S}_{3}$ turnsoff, the polarities of the coupled inductor are reversed, the body diode of $\mathrm{S}_{2}$ turn on to keeps the current $\mathrm{i}_{\mathrm{LS}}$ flowing. $\mathrm{S}_{1}$ body diode also turns on. Although the secondary current $i_{\text {LS }}$ decreases, the primary current $i_{L P}$ remains same. When $S_{1}$ and $S_{2}$ turns on $C_{2}$ starts discharging across the low voltage side of the circuit through switch $S_{2}$ and inductor $\mathrm{L}_{1}$. Thus, the secondary current is induced in reverse by discharging capacitor $\mathrm{C}_{2}$. Clamp capacitor $C_{1}$ also discharges through diode $D_{2}$ by adding small current $i_{3}$ into the secondary current flowing into the low voltage side of the circuit.

The voltage gain is $\frac{\mathrm{V}_{\mathrm{L}}}{\mathrm{V}_{\mathrm{H}}}=\frac{\mathrm{D}}{1+\mathrm{n}-\mathrm{nD}}$

The inductor of Boost and Buck mode can be expressed from the average current and load current[12].

$$
\mathrm{L}_{\mathrm{M}(\text { boost })}=\frac{\mathrm{D}(1-\mathrm{D})^{2} \mathrm{RTs}}{2(\mathrm{n})^{2}}
$$

(9)

$\mathrm{L}_{\mathrm{M}(\text { buck })}=\frac{(1-\mathrm{D})(1+\mathrm{n}-\mathrm{nD}) \mathrm{RTs}}{2(1+\mathrm{n}-\mathrm{nD})}$

\section{Topology 4}

NBDC for charging and discharging the battery bank through single circuit in applications of Uninterruptible Power Supplies and hybrid electric vehicles is given in Figure 5. This converter operates under zero-voltage switching condition and provides large voltage diversity in the both modes of operation. This enables the circuit to step up the lowbattery bank voltage to high dc-link voltage, and vice versa by employing only three switches, a coupled inductor, and an additional voltage clamped circuit [10].

In Boost mode, switch $\mathrm{S}_{1}$ and diode $\mathrm{D}_{\mathrm{S} 3}$ are turned on. The energy stored in the leakage inductor $\mathrm{L}_{\mathrm{K} 2}$ is released to capacitor $\mathrm{C} 2$, and $\mathrm{i}_{\mathrm{LK} 2}$ and $\left(\mathrm{i}_{\mathrm{S} 3}\right)$ are gradually decreased. The battery voltage $\mathrm{V}_{\mathrm{L}}$ releases energy into the leakage inductor $\mathrm{L}_{\mathrm{K} 1}$. Thus, the leakage inductor current $i_{L K 1}$ rapidly increases. $V_{L}$ charges the magnetizing inductor $\mathrm{L}_{\mathrm{M}}$ and the leakage inductor $\mathrm{L}_{\mathrm{K} 1}$. The magnetizing-inductor current $\mathrm{i}_{\mathrm{LM}}$ and the leakage-inductor current $\mathrm{i}_{\mathrm{LK} 1}$ are linearly increased. $S_{1}$ is turned off, and $D_{\mathrm{S} 2}$ and $D_{\mathrm{S} 3}$ are turned on. Theenergy of $\mathrm{Lm}$ is released into $\mathrm{C}_{\mathrm{H}}$ via the coupled-inductor and $\mathrm{D}_{\mathrm{S} 3}$. $\mathrm{I}_{\mathrm{LM}}$ linearly decreases, and the energy stored in $\mathrm{C}_{2}$ is transferred to $\mathrm{C}_{\mathrm{H}}$ and $\mathrm{R}_{\mathrm{H}}$. The voltage gain is, $\quad \frac{\mathrm{V}_{\mathrm{H}}}{\mathrm{V}_{\mathrm{L}}}=\frac{2+\mathrm{nD}}{1-\mathrm{D}} \quad$ (11)In Buck mode, switches $S_{2}$ and $S_{3}$ are turned on, and $D_{4}$ is turned off. The voltage source $\mathrm{V}_{\mathrm{H}}$ charges $\mathrm{L}_{\mathrm{M}}$. The voltage across the primary winding is equal to $V_{P}, i_{L M}$ linearly increases. The DC bus voltage $\mathrm{V}_{\mathrm{H}}$ releases its energy to $\mathrm{C}_{2}, \mathrm{C}_{\mathrm{L}}$, and $\mathrm{R}_{\mathrm{L}}$. If $\mathrm{S}_{2}$ and $\mathrm{S}_{3}$ are turned off, andD $D_{S 1}$ is turned on. $L_{M}$ not only releases its energy into $C_{L}$ and $R_{L}$ but also transfers energy to $C_{2}$ via $N_{S}$ and $\mathrm{D}_{4}$. $\mathrm{I}_{\mathrm{LM}}$ linearly decreases. The voltage gain is,

$\frac{V_{L}}{V_{H}}=\frac{D(1-D)}{2 n(1-D)^{2}+1}$

The inductor should be designed as high enough to minimize the ripples and associated losses. The minimum critical inductance can be obtained from inductor ripple current, average input and output inductor current [12].

$\mathrm{L}_{\mathrm{M}}=\frac{\mathrm{D}(1-\mathrm{D}) 2}{2 \mathrm{n}^{2}} \mathrm{~T}_{\mathrm{S}}$

Table 1 lists the design parameters of all the four topologies used in simulation. The low voltage side, high voltage side and switching frequency are common for all the four selected topologies. The passive device values are calculated with help of above mentioned analysis.

Table 1. Design specifications

\begin{tabular}{|c|c|c|c|c|}
\hline & $\begin{array}{c}\text { TOPOLO } \\
\text { GY } 1\end{array}$ & $\begin{array}{c}\text { TOPOL } \\
\text { OGY } 2\end{array}$ & $\begin{array}{c}\text { TOPOLOG } \\
\text { Y } 3\end{array}$ & $\begin{array}{c}\text { TOPOL } \\
\text { OGY } 4\end{array}$ \\
\hline $\begin{array}{l}\mathbf{V}_{\mathbf{L}} / \\
\mathbf{V}_{\mathrm{H}}\end{array}$ & $\begin{array}{c}24 \mathrm{~V} / 260 \\
\mathrm{~V}\end{array}$ & $\begin{array}{l}24 \mathrm{~V} / \\
260 \mathrm{~V}\end{array}$ & $24 \mathrm{~V} / 260 \mathrm{~V}$ & $\begin{array}{l}24 \mathrm{~V} / \\
260 \mathrm{~V}\end{array}$ \\
\hline$\overline{\mathbf{P}_{0}}$ & $500 \mathrm{~W}$ & $500 \mathrm{~W}$ & $500 \mathrm{~W}$ & $500 \mathrm{~W}$ \\
\hline$\overline{\mathbf{F}_{\mathrm{S}}}$ & $30 \mathrm{KHZ}$ & $30 \mathrm{KHZ}$ & $30 \mathrm{KHZ}$ & $30 \mathrm{KHZ}$ \\
\hline $\mathbf{L}$ & $\begin{array}{l}\mathrm{L}_{1} \geq \\
900 \mathrm{mH} \\
\mathrm{L}_{2} \geq 9.5 \mu \mathrm{H}\end{array}$ & $\begin{array}{c}\mathrm{L}_{\mathrm{S}}= \\
1.3 \mathrm{Mh}\end{array}$ & $\begin{array}{l}\mathrm{L}_{1}=\mathrm{L}_{2}= \\
1 \mu \mathrm{H}\end{array}$ & $\begin{array}{l}\mathrm{L}_{2} \geq \\
80 \mu \mathrm{H}\end{array}$ \\
\hline $\mathbf{C}$ & $\begin{array}{l}\mathrm{C}_{1} \geq 64 \mu \mathrm{F} \\
\mathrm{C}_{\mathrm{H}}=\mathrm{C}_{\mathrm{L}} \geq \\
96 \mu \mathrm{F}\end{array}$ & $\begin{array}{l}\mathrm{C}_{1} \geq \mathrm{C}_{2} \\
\geq 3.3 \mathrm{Mf}\end{array}$ & $\begin{array}{l}\mathrm{C}_{\mathrm{L}} \geq 220 \\
\mu \mathrm{FC}_{2} \geq \mathrm{C}_{\mathrm{H}} \\
\geq 330 \mu \mathrm{F}\end{array}$ & $\begin{array}{l}\mathrm{C}_{2} \geq \mathrm{C}_{1} \\
\geq 4.4 \mu \mathrm{F}\end{array}$ \\
\hline
\end{tabular}




\section{SIMULATION AND RESULTS}

The simulation is carried out using MATLAB - SIMULINK software. Except topology 1 , the other topologies are having coupled inductor with turns ratio $\mathrm{N}=3$. Coupled inductor design $\mathrm{M}=\mathrm{K} \sqrt{ } \mathrm{L}_{1} \mathrm{~L}_{2}$

Where $\mathrm{k}=$ coupling coefficient,

$\mathrm{L}_{1} \mathrm{~L}_{2}=$ primary and secondary inductance

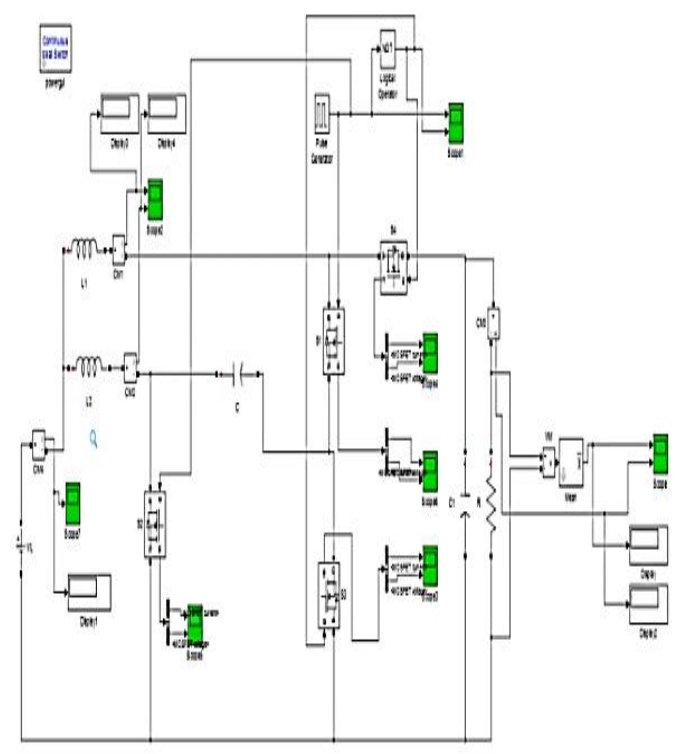

(a)

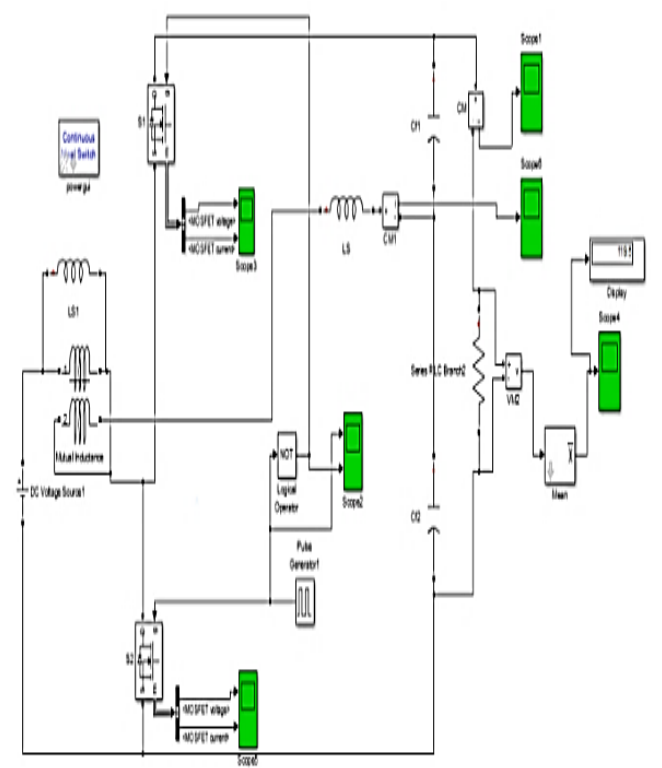

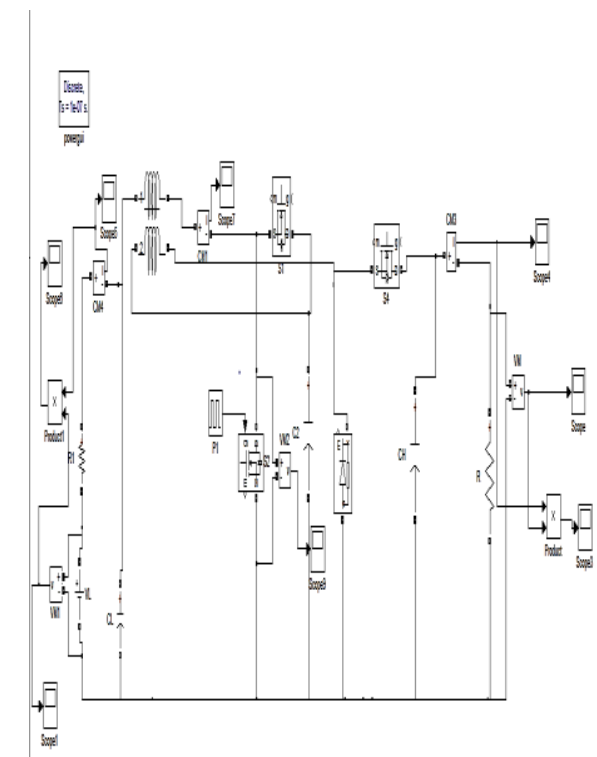

(c)

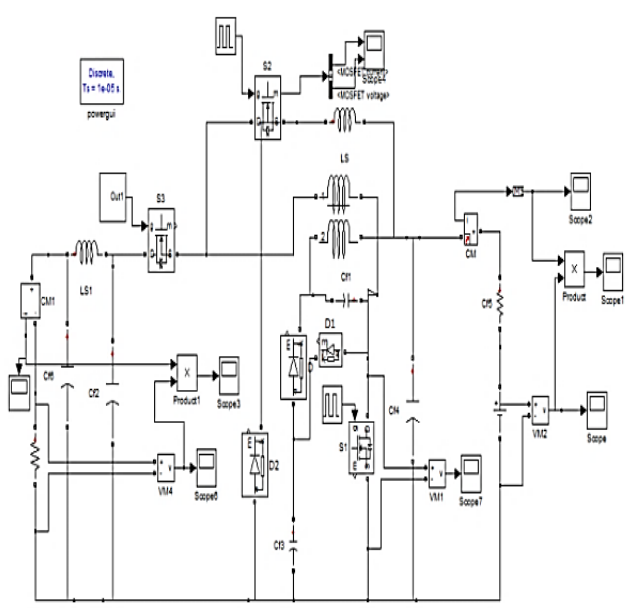

(d)

Figure 3. Simulink Model (a) Topology 1, (b) Topology 2,

(c)Topology 3, (d) Topology 4

The switches which are controlled for discharging and charging mode with duty ratio is given separately for all the four topologies in table 2. The input, output voltage and output power is common for all the topologies. Only the input power varies due to the large inrush of

Table 2 Operating switches and duty cycle for each topologies

\begin{tabular}{|c|c|c|c|c|}
\hline $\begin{array}{c}\text { TOPOLOGI } \\
\text { ES }\end{array}$ & $\begin{array}{c}\text { BOOST } \\
\text { SWITCH } \\
\text { ES }\end{array}$ & $\begin{array}{c}\text { DUT } \\
\text { Y } \\
\text { ratio }\end{array}$ & $\begin{array}{c}\text { BUCK } \\
\text { SWITCH } \\
\text { ES }\end{array}$ & $\begin{array}{c}\text { DUT } \\
\text { Y } \\
\text { ratio }\end{array}$ \\
\hline 1 & 1,2 & 0.69 & 3,4 & 0.3 \\
\hline 2 & 2 & 0.8 & 3 & 0.28 \\
\hline 3 & 1 & 0.7 & 2,3 & 0.3 \\
\hline 4 & 2 & 0.6 & 1,3 & 0.3 \\
\hline
\end{tabular}


current at the input side. So the efficiency also varied.In Boost mode, for a given input voltage of 24 $\mathrm{V}$ the maximum output voltage obtained as $250 \mathrm{~V}$. similarly in Buck mode, the input voltage is given as $260 \mathrm{~V}$ the output voltage obtained as $24 \mathrm{~V}$.

The efficiency is calculated for all the topologies by using below equations.

Efficiency $(\%)=\frac{\text { Output power }}{\text { Input power }}$

Output power $=$ output voltage $\times$ output current Input power $=$ input voltage $\times$ input current.The efficiency of the third topology is better than the other topologies in both boost and buck mode which is shown in figure 4.

Figure 4. Efficiency of discharging and charging mode for all the topologies

Table 3. Design specifications

\begin{tabular}{|l|l|}
\hline COMPONENTS & SPECIFICATIONS \\
\hline $\begin{array}{l}\text { Power switch } \\
\text { MOSFET }\end{array}$ & IRFP250 \\
\hline MOSFET Driver IC & IR2110, 2A, 500V \\
\hline Voltage Regulator IC & LM 7812, LM 7912, 5V \\
\hline Step down transformer & 230/18 V \\
\hline $\begin{array}{l}\text { Diodes fast } \\
\text { High frequency } \\
\text { recovery diodes }\end{array}$ & BY299, BY399,3 amps, 500v \\
\hline $\begin{array}{l}\text { High frequency } \\
\text { transformer(coupled } \\
\text { inductor type) }\end{array}$ & ETD 39 ferrite core \\
\hline
\end{tabular}

\begin{tabular}{|l|l|}
\hline Opto-coupler IC & MCT2E \\
\hline Battery & $12 \mathrm{~V}, 7 \mathrm{Ah}$ \\
\hline Capacitors & $\begin{array}{l}220 \mu \mathrm{F}, 100 \mathrm{~V}, 220 \mu \mathrm{F}, 250 \mathrm{~V} \\
2200 \mu \mathrm{F}, 50 \mathrm{~V}, 470 \mu \mathrm{F}, 25 \mathrm{~V}\end{array}$ \\
\hline Ceramic capacitor & $0.1 \mathrm{Pf}$ \\
\hline Logic gates & AND 4081, NOT 4049 \\
\hline Operational Amplifier & CA3140A,LF347 \\
\hline
\end{tabular}

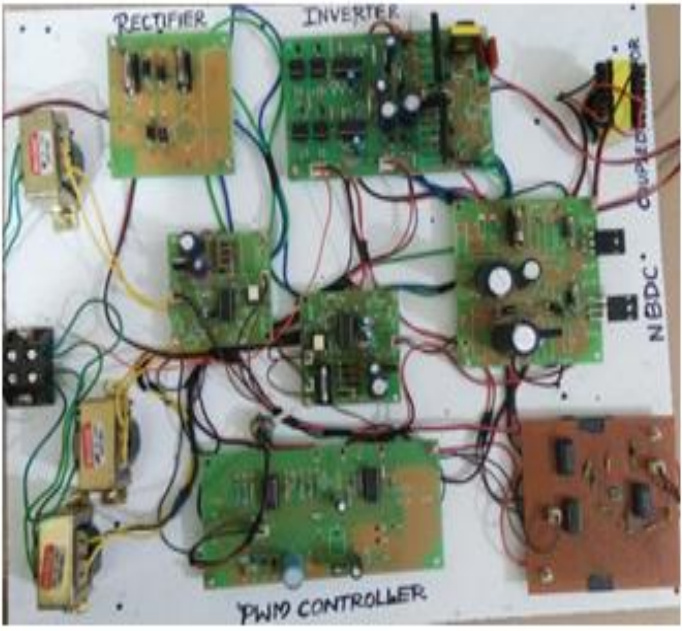

Figure5. HardwaremodelofNon-Isolated Bidirectional DC-C converter for UPS application

Table 4. Comparison of four topologies

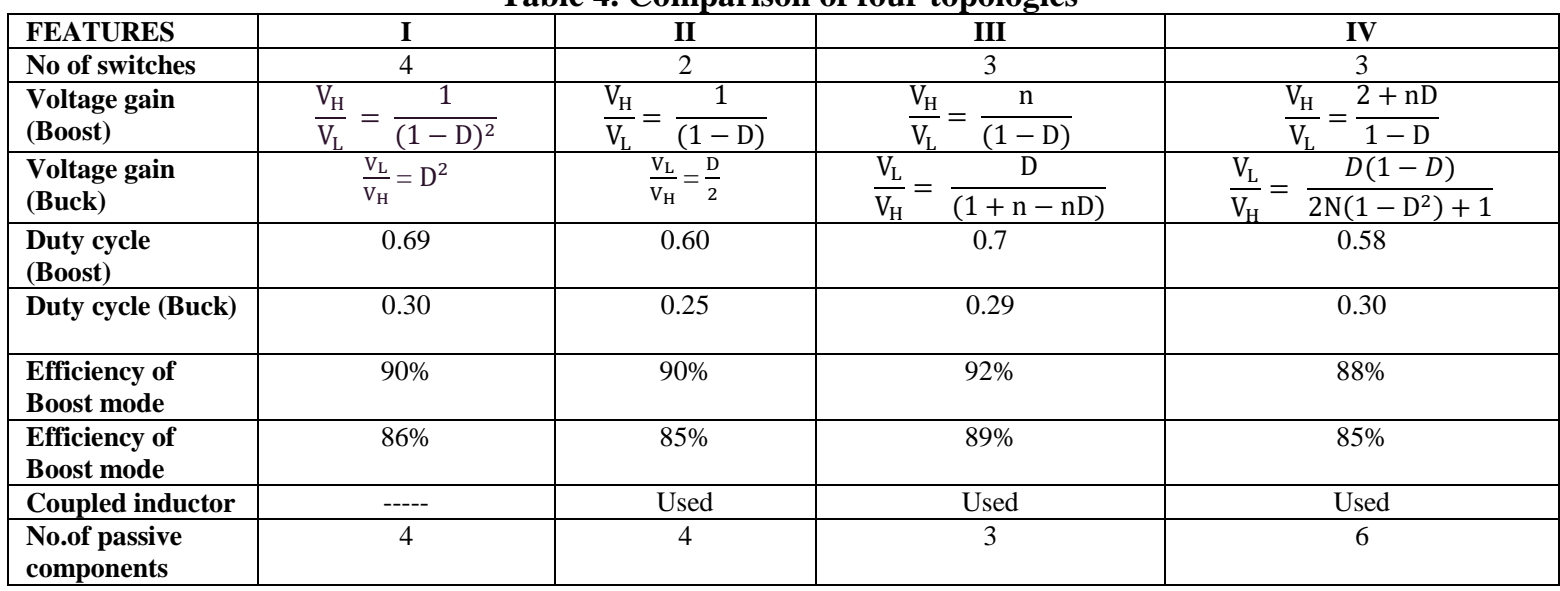

The table 4 provides the comparison of Boost and Buck mode for all the topologies. From the table, the minimum number of switches used in topology 2 but the number of passive components and operation of the circuit is complex then the efficiency is also reduced when compared to the other topologies. With very low duty cycle, the output voltage was obtained in topology 4 still the active and passive components are high and the efficiency is less than the other topologies. In topology 3 there are three switches used, the number of passive components and the efficiency is better. Also the circuit operation is like two stage Buck /Boost converter. Hence it gives high efficiency. 


\section{EXPERIMENTAL VALIDATION}

Hardware is done as a lab-scale model considering the cost, compactness and availability of the devices. The main $230 \mathrm{~V}$ AC is stepped down to $50 \mathrm{~V}$ is given to full bridge AC-DC rectifier which reduce the ripples and provide $\mathrm{DC}$ voltage. Now the $\mathrm{DC}$ voltage is converter into AC voltage to feed the AC load by using single phase full bridge inverter. At the same time DC bus voltage charges the battery to 12 VDC through the Non-isolated Bidirectional DC-DC converter. If the supply is off, the battery provides supply to the load. The PWM controller (IC based) circuit is used to operate the switches of the converter. The components used for hardware is listed in table 3 .

\section{Experimental results for inverter}

Here Sinusoidal PWM approach is used. In this method a triangular wave is compared to a sinusoidal wave of desired frequency and the relative levels of the two waves is used to control the switching of devices in each phase leg of the inverter. The input waveforms of sinusoidal and triangular waves are shown in figure $6(\mathrm{~b}),(\mathrm{c})$. The
Amplitude modulation index $\left(\mathrm{M}_{\mathrm{A}}\right)$ is defined as the ratio of reference amplitude and carrier amplitude.

$$
M_{A}=A_{r} / A_{c} \quad\left(0 \leq M_{A} \leq 1\right) \text { if } M_{A}>1 \text { for }
$$

over modulation.

Here the reference voltage of the inverter is set to $A_{r}$ $=4 \mathrm{~V}$, the carrier voltage is always constant $\mathrm{A}_{\mathrm{c}}=5 \mathrm{~V}$ then,

$$
\mathrm{M}_{\mathrm{A}}=0.8
$$

Since the single phase full bridge inverter has four switches, the gate pulse for switches $S_{A}, S_{D}$ and $\mathrm{S}_{\mathrm{B}}, \mathrm{S}_{\mathrm{C}}$ is shown in figure $6(\mathrm{~d})$. Inverter output voltage $=0.8 \times \mathrm{V}_{\text {IN }}=40 \mathrm{~V}$

The output voltage across the AC load was $40 \mathrm{~V}$ is shown in figure 6(e).

\section{Experimental results for converter}

In charging mode, the voltage gain is $\frac{\mathrm{V}_{\mathrm{L}}}{\mathrm{V}_{\mathrm{H}}}=\frac{\mathrm{D}}{(1+\mathrm{n}-\mathrm{nD})}$ $\mathrm{D}=0.5\left(\right.$ Where $\mathrm{V}_{\mathrm{L}}=12 \mathrm{~V}, \mathrm{~V}_{\mathrm{H}}=50 \mathrm{~V}, \mathrm{n}=3$. $)$

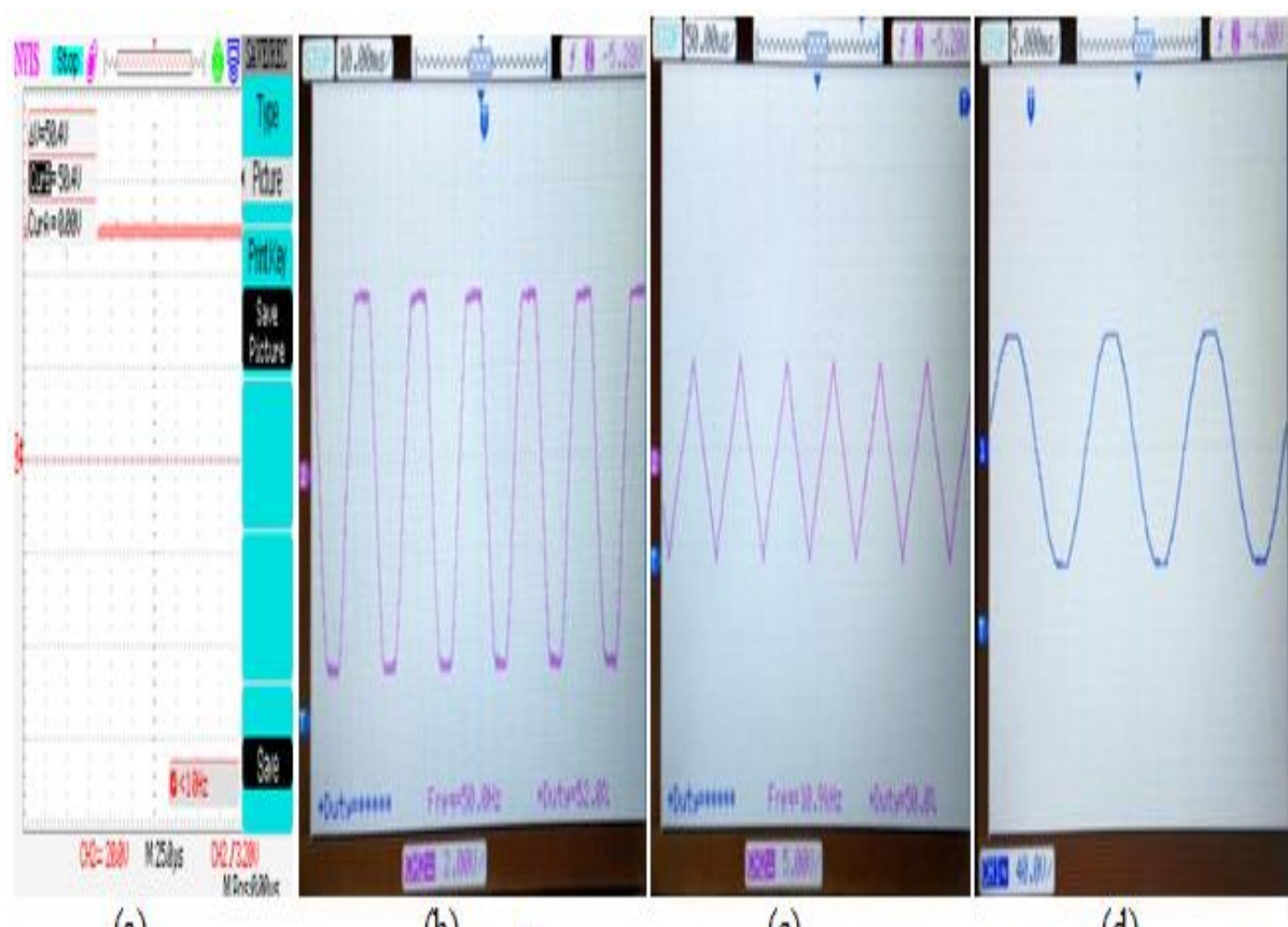

(a)

(b)

(c)

(d) 


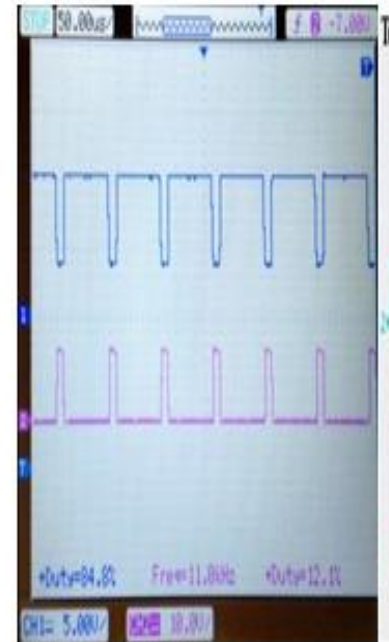

(e)

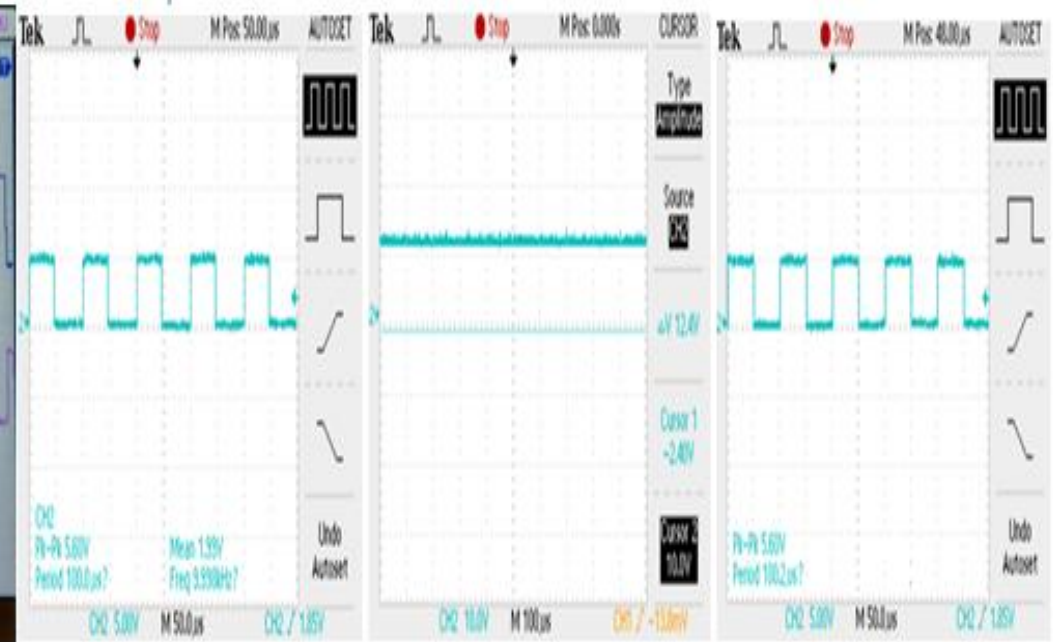

(f) (h)

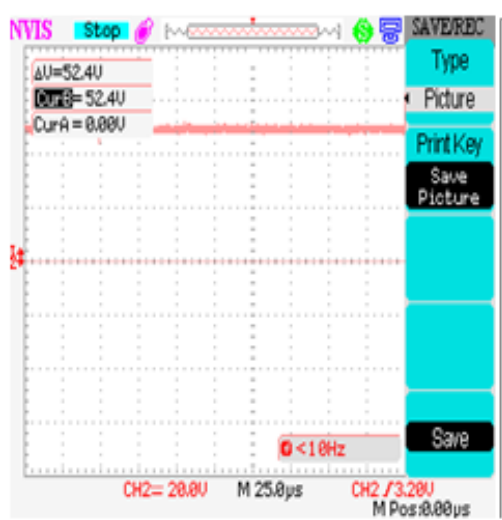

(i)

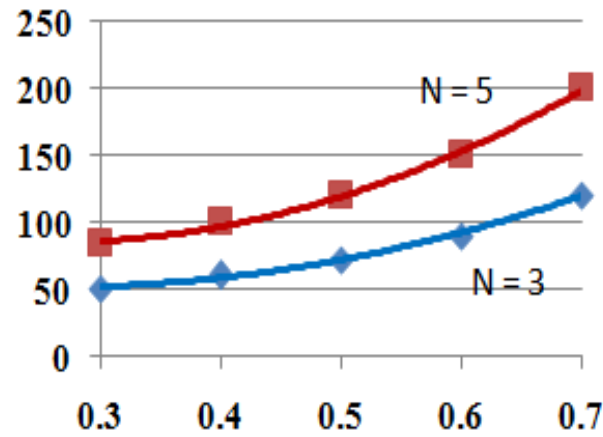

(j)

Figure 6 Experimental results (a) DC bus voltage, (b) Sinusoidal wave $A_{r}=4 \mathrm{~V}$, (c) Triangular $A_{c}=5 \mathrm{~V}$, (d) Output voltage of inverter, (e) Gate pulse of inverter switches $S_{A} S_{D}$ and $S_{B} S_{C}$,

(f) Gate pulse of converter switches $S_{1} S_{2}$, (g) Output voltage of charging mode , (h) Gate pulse of converter switches $S_{2} S_{3}$, (i) Output voltage of discharging mode, (j) duty ratio versus output voltage with different turns ratio

In Discharging mode, the voltage gain is $\frac{\mathrm{V}_{\mathrm{H}}}{\mathrm{V}_{\mathrm{L}}}=\frac{\mathrm{n}}{(1-\mathrm{D})}$ $\mathrm{D}=0.4 \quad\left(\right.$ Where $\mathrm{V}_{\mathrm{L}}=12 \mathrm{~V}, \mathrm{~V}_{\mathrm{H}}=50 \mathrm{~V}, \mathrm{n}=3$.)

When the supply is on, the DC bus voltage feeds the AC load and charging the battery.

At this time, the Non-isolated Bidirectional DC-DC converter acts as Buck mode by turning on the switches $S_{2}$ and $S_{3}$ to reduce the voltage. In order to distribute the continuous voltage to the

load even when there is no power supply, the Nonisolated Bidirectional DC-DC converter acts as Boost mode by turning on the switch $\mathrm{S}_{1}$ to increase the voltage to $52.4 \mathrm{~V}$ from the $12 \mathrm{~V}$ battery.

\section{CONCLUSION}

A Non-Isolated Bidirectional DC-DC Converter (NBDC) of various topologies is selected due to their unique characteristics compared with isolated type. Many topologies are implemented for different applications here four topologies are selected for Uninterruptible Power Supply system (UPS) because of the increased demand of power. The circuit principle and their operating modes for both step up and step down conversion are explained in detail. The design calculation and specifications are also discussed. All the topologies of low voltage side is connected with $24 \mathrm{~V}$ and high voltage side is connected with $260 \mathrm{~V}$. The simulation is done in Matlab/Simulink environment. From the simulation results and comparative study, the third topology is selected as the effective topology by considering the number of switches used, number of passive components and efficiency. A prototype model of $12 \mathrm{~V} / 50 \mathrm{~V}$ is implemented to verify the effectiveness of the converter.

\section{REFERENCE}

[1]. Edelmoser K.H and Himmelstoss F.A (2004), 'Bidirectional DC-to-DC Converter for Solar 
Battery Backup Applications', 35 ${ }^{\text {th }}$ Annual IEEE Power Electronics Specialists Conference,Germany, pp.2070-2074.

[2]. Garcia F.S. ,Pomilio J.A. and Spiazzi G (2012) 'Comparison of Non-Insulated, High-Gain, HighPower, Step-Up DC-DC Converters', IEEE, pp.1343-1347.

[3]. Hossein Ardi, Ali Ajami, FaezehKardan, and ShahlaNikpourAvilagh, (2016), 'Analysis and Implementation of a Non-Isolated Bidirectional DC-DC Converter with High Voltage Gain', IEEE Transactions on Industry Applications, Vol.63, pp.4878-4888.

[4]. HuaBai, Chris Mi (2012), 'Comparison and evaluation of different DC/DC topologies for plugin hybrid electric vehicle chargers',Int. J. Power Electronics, Vol. 4, No. 2.

[5]. Hyun-Lark Do (2011), 'Non-isolated Bidirectional Zero-Voltage-Switching DC-DC Converter', IEEE Transactions on Power Electronics, Vol.26, pp.2563-2569.

[6]. Karthikeyan V. and Rajesh Gupta (2013), 'Performance Study of Bidirectional DC-DC Converter', International Conference on Advanced Computing and Communication Systems, Coimbatore, pp.19-21.

[7]. KostiantynTytelmaier, OleksandrHusev, OleksandrVeligorskyi, Roman Yershov (2016), 'A Review of Non-Isolated Bidirectional DC-DC Converters for Energy Storage Systems', International Young Scientists Forum on Applied Physics and Engineering.

[8]. Manu Jain, Daniele M. and Praveen K. Jain (2000), 'A Bidirectional DC-DC Converter Topology for Low Power Application', IEEE Transactions on Power Electronics,Vol.15, pp.595-606.

[9]. Muhammad Aamir, Kafeel Ahmed Kalwar and SaadMekhilef (2016) 'Review: Uninterruptible Power Supply (UPS) system', Renewable and Sustainable Energy Reviews, Vol.58, pp. 1395 1410.

[10]. Muhammad Aamir, SaadMekhilef, and Hee-Jun Kim (2015), 'High-gain zero-voltage switching bidirectional converter with a reduced number of switches', IEEE Transactions On Circuits and

[17]. Storage System', IEEEInternational Conference on Power Electronics, Intelligent Control and EnergySystems
Systems,

Vol. 62, pp.816-820.

[11]. NavinkumarRaol L. and Gairola S. (2016), 'A Comparative Study of Bidirectional DC-DC Converter \& its Interfacing with Two Battery

[12]. Sasikumar S. and Krishnamoorthy K. (2015), 'A Literature Survey on Bidirectional DC to DC Converter', IJLTEMAS, Volume IV, ISSN 2278 2540.

[13]. Schupbachj R.M and Balda C. (2003), 'Comparing DC-DC Converters for Power Management in Hybrid Electric Vehicles',IEEE.

[14]. SerkanDusmez, Amin Hasanzadeh (2014), 'Loss Analysis of Non-Isolated Bidirectional DC/DC Converters for Hybrid Energy Storage System in EVs',IEEE.

[15]. Tsorng-Juu Liang, Hsui-Hao Liang, Shih-Ming Chen, Jiann-Fuh Chen and Lung-Sheng Yang (2014), ' Analysis, Design, and Implementation of a Bidirectional Double-Boost DC-DC converter', IEEE Transactions on Industry Applications, Vol.50, pp.3955-3962.

[16]. Wang K. , Lin C.Y., Zhu L., QuD.,Lee F.C and Lai J.S. (1998), 'Bidirectional dc-dc converters for fuel cell systems', IEEE Trans. Power Electron., Vol.13, pp.47-51.

\footnotetext{
International Journal of Engineering Research and Applications (IJERA) is UGC approved Journal with Sl. No. 4525, Journal no. 47088. Indexed in Cross Ref, Index Copernicus (ICV 80.82), NASA, Ads, Researcher Id Thomson Reuters, DOAJ.

K V Nirmala. "A Comparative Study of Four Different Non-Isolated Bidirectional DC-DC Converters." International Journal of Engineering Research and Applications (IJERA) 7.7 (2017): 76-83.
} 